\title{
THE FIXED MEANS: AN ACCOUNTING CONCEPT OR A FISCAL ONE?
}

\author{
Rotilă Aristița \\ "Vasile Alecsandri” University of Bacău, Romania \\ rotila11@yahoo.com
}

\begin{abstract}
Starting from the analysis of the accounting regulations applied to the economic operators, in their evolution after 1989, the specific accounting regulations for certain fields of activity and for certain categories of entities and starting from the fiscal rules and some paper works, we want to clarify in this study some conceptual issues referring to the fixed means, the tangible fixed assets components, of impacting financial information, respectively, on taxation. Is the concept of "fixed means" an accounting one or a fiscal one? We try to answer to this question and also to formulate an opinion on whether it is longer justified to use this concept in the accounting vocabulary and hence in the production of information presented in financial statements or in the fiscal vocabulary and implicitly in the work done to produce information provided in the fiscal reports.
\end{abstract}

\section{Keywords}

fixed means; tangible fixed assets; tangible immobilizations; inventory objects; fiscal; accounting regulations

\section{JEL Classification}

M41

\section{Introduction}

It is known that such material assets held by an entity for using them in the production processes of goods, services, for rental to others or for administrative purposes, longer than one year are encountered in accounting as the tangible fixed assets (tangible immobilizations). In post-revolutionary Romania, both in legislation of accounting and taxation, and accounting literature and practice it was maintained and used for a long period of time the term of fixed means, in order to define the tangible fixed assets, other than land and land improvements. So, the tangible assets included: land and fixed means. Later on, while the Romanian accounting is harmonized with the European accounting directives and respectively to the international standards, this syntagma fixed means is used more and more less explicitly in the accounting regulations and, as a consequence, and in the accounting literature, but it is still used in taxation laws. Therefore, a question appears: whether the fixed means still represent an accounting concept or it is just a concept in taxation. In the following lines we try to clarify such issues and clarify if the term fixed means it is still available in the accounting vocabulary or only in taxation language and implicitly in the work done to produce the information provided in the fiscal reports. Thus, we proceeded to analyze the accounting regulations applied to the economic operators in their evolution after 1989, the specific accounting regulations applicable to certain categories of economic entities in various fields of activity, as well as the taxation rules and some specific papers works. 


\section{The concept of "fixed means" in the accounting regulations and taxation norms}

The concept of fixed means, in the Romanian accounting in a centralized economy, used to define the economic means of "long life use" is still used after 1989. Immediately after 1990, by achieving a "makeover" to the old accounting system, in its adaptation to the urgent requirements arising from the adoption of the first laws of the market economy, the concept of fixed assets (immobilized assets) was introduced, among other concepts, in addition to the classic accounting vocabulary. A legal framework was also developed for organizing and conducting accounting by every patrimonial entity, namely the Accounting Law no. 82/1991. In the initial version of the Accounting Law the term of fixed means is used in the context to formulate the following requirement: "accounting fixed means is achieved on categories and individual items” (Art. 13, para. 1). Later on, it was elaborated the Regulation for implementing the Accounting Law (approved by Government Decision no. 704/1993), where the fixed means are defined as a component of the tangible fixed assets. In the above Regulation, after stating that "within tangible assets are included land and the fixed means" (point 52), the definition for the latter is formulated, as follows: "a fixed mean is considered to be a singular or a complex object which is used as it is and satisfies cumulatively the following conditions: a) its value is higher than the limit established by the law; b) its normal duration of use lasts longer than one year" (point 53). Also, there are specified some categories of fixed means that must be taken into account, such as: "buildings; special constructions; machinery and industrial installation; apparatus and installation for measurement, control and regulation; means of transport; working animals; plantations; tools, household inventory and other fixed means (including packaging as fixed means)".

What it happens to those goods that do not meet either the value condition or the lasting condition, to be considered fixed means? In the mentioned Regulation that they are considered as inventory objects, a separate category within stocks. According to the Regulation (point 63), the inventory objects are "goods with a value below the limit required by the law, as to be considered fixed means, regardless of their length of service or in use for less than one year, no matter their value and the goods assimilated, such as protective equipment, work equipment, special clothing, mechanisms, devices, checkers, SDV, measurement and control devices, molds used to manufacture certain products and similar items”.

It should be noted that the Charts of Accounts, approved at the same time with the Regulation implementing the Accounting Law has different reserved accounts for the two categories of goods, namely 212 "Fixed means" with related sub-categories of assets mentioned above, and 321 "Inventory objects".

In the same period of time was approved the Law no. 15/1994 regarding the depreciation of the immobilized capital in tangible and intangible assets, the Methodological Rules (Order of the Ministry of Finances (MF) no. 746/1994) and the Classification and Durations of normal functioning of fixed means (Government Decision no. 266/1994) were also approved. According to Law no. 15/1994, Art. 3, "the tangible assets related to immobilized capital are: a) land, including investments in their arrangement; b) fixed means”. For the fixed means there is a similar definition with the Regulations for implementing the Accounting Law.

Starting from 1999, a new stage in the evolution of Romanian accounting began, marked by the development, by the Ministry of Finance, of the National Program of harmonization of accounting legislation with the European Directives and assimilation of the International Accounting Standards. At this stage, it was achieved, on the one hand, the "Romanian accounting internationalization" and, on the other hand, the "Romanian accounting Europeanization", by developing, by the body of 
normalization, also the practical implementation, of two sets of accounting regulations, as follows:

- the accounting regulations harmonized with the IV-th Directive of EEC and the International Accounting Standards, approved by the Order of MF no. 403/1999, subsequently modified and approved by the new version of Order of the Ministry of Public Finances (MPF) no. 94/2001);

- simplified accounting regulations harmonized with the European Directives, approved by Order of MPF no. 306/2002.

The accounting regulations approved by Order no. 94/2001 use the concept of fixed means but do not defined this concept, for example, when it present the rules on the valuation of the elements of balance sheet on the date to entering into patrimony (point 5.13); when it formulates requirements relating to disclosure in the explanatory notes (point 5.62, letter c); or when it presents cash flows from investing activities in the Cash flow statement. In the accounting regulations approved by Order no. 306/2002 the fixed means does not appear explicitly (only by chance in the rules of operating the accounts), but the definition for the tangible immobilizations is equivalent of that of the fixed means from the previous accounting regulations (point 4.25): "Tangible immobilizations are assets that :

a) are owned by a legal entity for use in its production of goods or services, for rental to others, or for administrative purposes;

b) are used over a period longer than one year; and

c) their value is higher than the limit set by the regulations in force.”

It may be noted that this definition differs from the one found in the European Directives by including a condition in value. The European Directives, as international standards, contain the definition of fixed assets include only two conditions, destination and duration, considering the fixed assets "those assets for use on a continuing basis for the purposes of a company activities”.

Referring to the Chart of Accounts approved both by Order no. 94/2001 and then by Order no. 306/2002, one may find that the account entitled "Fixed means" has been removed, only specific accounts to different categories of fixed means appear. Also, the account 321 entitled "Inventory objects" has been removed and replaced with the 303 account "Materials in the form of Inventory Objects".

We must point out that, at this stage, the term fixed means was removed even in the Accounting Law (through amendments brought by the Government Ordinance no. 61/2001), which was replaced by the concept immobilized assets, a more comprehensive accounting structure.

In preparation for adherence of Romania to the EU, new regulations were elaborated, they ensure the full transposition of mandatory provisions of the European Directives and some of their optional provisions, whose takeover is left at the discretion of the Member States. It is about the accounting regulations compliant with the European Directives, approved by Order of MPF no. 1752/2005, for the economic operators, subsequently modified / completed and approved by the new version of the Order of the MPF no. 3055/2009. Since 2012, the companies whose securities are admitted to trade on a regulated market apply the accounting regulations compliant with the International Financial Reporting Standards (IFRS) approved by Order of the MPF no. 1286/2012. In the content of all these regulations, the term fixed means is not found, but only the term of tangible immobilizations. The accounting regulations compliant with European Directives (point 92), define the tangible immobilizations the same as the international standards such as: "Tangible immobilizations are assets that:

a) are held by an entity for use in the production of goods or services, for rental to others, or for administrative purposes; and

b) they are used over a period of time longer than one year." 
Also, from the accounting regulations compliant with the European directives it gives that a separate component in the structure of inventories it is represented by the "materials in the form of inventory objects" without explaining what they are. We believe that, as long as the expression "materials in the form of inventory objects" is used in the accounting regulations, the "inventory objects" should be defined.

The accounting regulations compliant with the IFRS, both in terms of the tangible fixed assets and in terms of stocks, do not define these concepts, but contain only specifications where it must be respected that the mandatory conditions set by IFRS, meaning that "fixed assets [. ..] are recognized under the terms of IFRS" (point 37), "an asset are classified as a current asset under the terms of IFRS" (point 53), "the recognition, measurement and deregistration of stocks is performed according to IFRS requirements" (point 55), "stocks are mentioned in accounting by their nature, in compliance with IFRS” (point 56). In addition, we no longer meet in the stock structure the "materials in the form of inventory objects", while complying to accounting regulations compliant with the IFRS, in order to transpose the account trial balances in the new Chart of Accounts, the account balance 303 "Material in the form of inventory objects" account being taken by 303 "Other materials". The accounting regulations compliant with the IFRS are also applied by credit institutions (Order of NBR no. 27/2010). Starting from their analysis, we find that, unlike economic operators, with the adoption of the regulations compliant with the IFRS, a clear distinction by duration was intended, between current assets and non-current assets, without taking into account the value factor valuable, the account balance 363 "Materials in the form of inventory objects" being transferred partly in stocks (account 3622 "Other supplies"), partly on fixed assets (4424 "Furniture, office equipment, protective equipment and human values equipment and other tangible fixed assets”).

So, the Romanian accounting regulations, as IFRS, require two conditions for a tangible asset to be recognized as an immobilized asset one: the condition of "destination" and the provided "duration" without setting a condition value. Therefore, the low-value goods, such as, for example, "trash basket", could be accounted as a fixed asset, as they have a useful life greater than one year (Toma, 2003). We think it would be necessary to limit the value which can define immobilized assets (fixed means) opposite to the goods having an useful life greater than one year, which have to be recognized in inventories (inventory objects). In the absence of such conditions, such as the limit of the value, we believe that we have no a legal basis to reflect as current asset (stock) a good with useful life of more than one year. In practice, as some authors approached the problem, there are two ways to solve it, as follows:

- by the accounting policies adopted, the management of a company sets the limit of value at which a good will be accounted for a fixed asset, regardless the taxation in this matter (Toma, 2003);

- $\quad$ in some cases, for convenience (Toma, 2003) and to simplify the work by keeping one row of records (Istrate, 2009), the management adopt the threshold set by the tax authority as and accounting threshold. Currently, in Romania, this threshold is 2.500 lei, an established value by the Government Decision no. 276/2013 (Art. 1, para. 1).

Related to the fixed means, some entries should be made in relation to the accounting regulations applicable to other categories of entities than the economic operators, namely:

- in accounting regulations compliant with the European Directives, applicable as appropriate, to private pension sector (Norm 14/2007 approved by Decision of Supervisory Commission of Private Pensions System no. 37/2007), in the capital markets (Order of National Securities Commission 
no. 12/2011) or in the banking sector (Order of NBR no. 27/2011), as we found also in the case of regulations applicable to the economic operators (Order of MFP no. 3055/2009), the concept of fixed means it is no longer used;

- the fixed means term appears in the accounting regulations applicable for the insurance sector (Order of Insurance Supervisory Commission (ISC) no. 3129/2005). Even if the actual text of these regulations do not use the term fixed means, however, the Chart of Accounts for insurance, at group 51 "Tangible assets of exploitation" the account 511 "Fixed means" appears, with a development of synthetic degree two account based on different categories of insurance, respectively the life insurances (5111 "Fixed means for life insurance") and general insurances (5112 "Fixed means for general insurances"), further developed on third degree synthetic accounts based on the categories of known fixed means (technological equipment; machinery and equipment for measurement, control and regulation; means of transport; furniture, office equipment, equipment for the protection of human values and material and other tangible assets), except construction. Construction is highlighted together with land as "investments in tangible immobilizations" using the 211 account "Land and buildings" with appropriate sub-accounts development.

- the accounting regulation applicable for the non-profit legal persons (Order of MFP no. 1969/2007) use the syntagma "tangible immobilizations in the form of fixed means". In Chapter II, on the single-entry accounting organization (B. point 10) it is noted "accounting of the tangible assets in the form of fixed means use the Sheet for fixed means [...]”.

A separate discussion should appear, related to the applicable accounting standards of the public institutions. The methodological norms regarding the organization and management of the accounting public institutions, approved by Order of MFP no. 1917/2005 uses the term tangible fixed assets. For them, we meet the following definition: "the tangible fixed assets are considered complex object or objects used as they are and meet the following conditions: their input value are higher than the limit set by a Government decision and their normal use is for a period of time greater than an year" (point 1.2.1). This is actually the definition of the fixed means, made in the Law 15/1994 (Art. 3).

The accounting rules applicable to different categories of entities mentioned above meet in the stocks structure the "materials in the form of inventory objects", without explaining what they are. Only the contents of the Methodological Norms for organizing and conducting public institutions accounting explain the definition of the inventory objects as they "represent goods with a value below the limit required by the law, to be considered tangible fixed assets, redardless the duration of use, or with a term of less than one year, regardless of their value, the goods similar as well (personal protective equipment, work equipment, special clothing, machinery, tools, devices, controllers, gauges and control etc.)" (point 2.1.2.3). This is actually the definition of inventory assets in the Regulation for implementing the Accounting Law no. 82/1991.

It should be noted that we meet further the concept of fixed means in the accounting rules relating to financial and accounting documents (approved by Order of the Ministry of Economy and Finance no. 3512/2008). Such specific documents, for example:

- the receipt for movement of fixed means - used as a supporting document that records the movement of fixed means inside the organization; 
- $\quad$ the inventory numbers register - used for fixed means records, assigning each means by itself, for identification, inventory number;

- the sheet for fixed means - assigned to each means, thus resulting the analytical accounting.

From a taxation perspective, the concept of fixed means is regulated by the Fiscal Code. The Fiscal Code, as reglementing the "Fiscal depreciation", defines the concept of "fixed means" as "any tangible fixed asset, which is held for use in the production or supply of goods or services or to be leased to others, or for administrative purposes, if the normal useful life lasts more than a year and has a value greater than the limit set by a Government Decision” (Art. 7, para. 16). The same definition is encountered in the Fiscal Code (Art. 24, para. 2) for the term "depreciable fixed means", too. In addition, both the Fiscal Code (Art. 24, para. 3 and para. 4) and the depreciation of the assets Law no. 15/1994, shows a list of items that are considered as "depreciable fixed means" as well as a list of items that are not considered "depreciable assets". The Fiscal Code also establishes clear rules on fiscal depreciation regimes accepted for each category of depreciable fixed means (Art. 24, para. 6), respectively:

a) in the case of construction, the method of linear amortization;

b) in the case of technological equipment or machines, tools and installations as well as for computers and peripherals, the company can decide the straight-line depreciation method the digressive or accelerated depreciation;

c) in the case of any other depreciable fixed means, it can be chosen linear or digressive method of depreciation.

For the calculation of fiscal depreciation, the Fiscal Code calls for the normal duration of use, representing durations of use for recover, from a fiscal standpoint, the input value of the fixed means, on the depreciation method. It is known that, since 2005, according to GD. 2139/2004, approving the Classification Catalogue and the normal durations of use of the fixed means "for each newly purchased fixed means it can be used variable intervals between a minimum and a maximum period of time”, each economic entity having "the possibility to choice the normal duration of use between these limits". GD. 2139/2004 (point I.4) states that "thus established, the normal duration of use of the fixed means remains unchanged until full recovery of the input value or its removal from service".

From the two categories of regulations, accounting and fiscal, related to fixed means / tangible assets, a number of differences results between their specific accounting and taxation. Particularly, the design and calculation of the depreciation of fixed means/ tangible assets is a problem with accounting and taxation implications. The accounting rules that underlie the financial statements are subject to fair representation and management in terms of efficiency of resources and results of the economic entity and taxation rules are subject to evaluation and calculation, recognition and settlement of taxes owed by the same entity (Ristea and Dumitru, 2012). The differences find expression in a series of elements considered as a double aspect, accounting and fiscal, as following: accounting depreciation, fiscal depreciation; accounting amortization period of use (useful life), fiscal depreciation period (during normal of use); the depreciable amount, diminished with (accounting) or not (fiscal) the residual value; depreciation methods accepted in accounting or in fiscality. Also, there are a number of differences between the accounting and fiscality rules applicable to fixed means/ tangible assets in terms of the possibility of changing the amortization period or the method of amortization. In this article, we not intend, however, to analyze these differences.

Regarding the accounting literature, the term fixed means is becoming less common, the authors use the terminology of the accounting regulations related to this issue. In some paper works (Paraschivescu et al, 2013; Horomnea et al, 2008), the authors use the term "tangible immobilizations in the form of fixed means". In other paper works, 
even the authors use not the term fixed means, when defining tangible assets, they include, in addition to the requirements of "destination" and "duration", the provided "value" also, from the definition of fixed means "the input value is greater as the limit established by laws" (Grosu et al, 2013). We also meet the term fixed means used in some representative paper works of literature for the specific economic and financial analysis, being addressed, for example, in the context of the internal potential of the company, to the "managerial analysis of the fixed means" (Robu, Anghel \& Şerban, 2014).

\section{The Law 15/1994 regarding the amortization: between accounting and fiscality}

As we mentioned, the concept of fixed means is regulated by the Law 15/1994 regarding the depreciation of the immobilized capital in tangible and intangible assets. The Law 15/1994, as it is amended and supplemented, asserts that the organizations with economic activities, which immobilizes capital in tangible and intangible assets submitted to the depreciation through use or time, "will calculate, will record in the accounts and recover the physical wear and their moral status to restore the assets value" (Art. 1) and that they "depreciate the fixed means under this law stipulations, using one of the following depreciation methods [...]" (Art. 18). In addition, Chapter 4 - Accounting depreciation of the fixed means and its destination - states that "businesses [...] are required to disclose in accounting, in separate accounts, the fixed means and their depreciation" (Art. 20). According to the accounting regulations compliant with the European directives for economic operators (point 112), the depreciation of tangible assets is calculated using where one of the following methods: the straight-line depreciation, the digressive depreciation, the accelerated depreciation, the amortization calculated per unit of product or service. To calculate depreciation under digressive method, "which is multiplying the linear amortization rates by a coefficient", the mentioned regulations refer to the legislation in force "in which case one can be envisage the current legislation". The legislation setting out the coefficients in question is the Law 15/1994, regarding the depreciation of the immobilized capital in tangible and intangible assets. On the other hand, the Fiscal Code clearly regulate the aspects of "fiscal depreciation" and even contains the stipulation (Art. 24, para. 22) that "the Law no. 15/1994, regarding the depreciation of the fixed immobilized capital in tangible and intangible assets, republished, with subsequent amendments, does not apply in calculating taxable profit, except to Art. 3, para. 2, letter a) and Art. 8 of the same law”. Art. 3, para. 2, letter a) specify the value condition from the definition of fixed means "a) has an input value greater than the limit established by a Government decision. This value can be annually updated based on the inflation index" and Art. 8 refers to the way the duration of use is set, namely "normal duration of use and the classification of fixed means shall be approved by a Government Decision. In their determination, the technical and economic parameters established by the designers and manufacturers, through the books or technical records of the fixed means will be taken into account, concerning the effects of obsolescence. These periods of time will be periodically reviewed, but not later than 5 years."

Thus, the Law 15/1994 is at a time an accounting or fiscal law? If at the beginning this law was both an accounting and a fiscal one, nowadays, it mainly remains an accounting rule, fiscality is strictly regulated by the Fiscal Code. Likewise, some authors stated in the literature that the accounting depreciation "is regulated by Law no. 15/1994 [...]” (Pântea and Bodea, 2008). As we consider the Law 15/1994 (where we find the fixed means properly defined) as an accounting rule, we have the legal 
basis to present, inside the stocks, those items that have a lower value but they have a useful life of more than one year (inventory objects).

\section{Conclusions}

In the traditional Romanian accounting, the tangible fixed assets immobilizations, except land and land improvements, formed a distinct structure, called "fixed means". In the context of the development and modernization of the Romanian accounting, harmonized with international and European accounting standards, in the Romanian accounting regulations on the financial statements the concept of "fixed means" was gradually abandoned (ever more and more), being used instead only the term tangible fixed assets (tangible immobilizations). The concept of "fixed means" is defined explicitly only in fiscal norms and in the legislation about depreciation, not in accounting regulations compliant with European directives or those under IFRS. However, this term is still used, but not defined in the accounting regulations applicable to certain categories of entities (insurers, non-profit legal persons) and in the rules related to the financial and accounting documents. Although the content of the accounting regulations compliant with European directives renounced to use the term "fixed means" the Chart of Accounts, however, a part of the regulations according to European directives, allows a distinction between fixed means and inventory objects, keeping an account entitled "Materials in the form of inventory objects”. The invocation, to fit a tangible active in the fixed assets (immobilizations), alongside to the two conditions, the destination and the duration of the of the value condition get from the definition of the fixed means, according to Law. 15/1994 (a value greater than the limit set by law) may justify the current asset classification, and present as they are in the financial statements, together with raw materials and consumables, while the inventory objects, participating in several operating cycles and so, their destination and their duration could be taken into account to qualify them as tangible fixed assets. We believe that the term fixed means stated by the Law no. $15 / 1994$, can be used both in the accounting vocabulary and in the fiscal vocabulary, even if it is not a distinct structure presented in the financial statements.

\section{References}

IASB (2011), Standardele Internaţionale de Raportare Financiară (IFRSs). Norme oficiale emise la 1 ianuarie 2011, Partea A, Bucureşti, Editura CECCAR.

Horomnea, E., Tabără, N., Budugan, D., Georgescu, I., Beţianu, L. (2008), Bazele contabilităţii: concepte, modele, aplicaţii, Iaşi, Editura Sedcom Libris.

Hotărârea Guvernului nr. 704/1993 pentru aprobarea unor măsuri de executare a Legii contabilităţii nr. 82/1991.

Legea contabilităţii $n r$. 82/1991, republished, with subsequent amendments.

Legea $n r$. 15/1994 privind amortizarea capitalului imobilizat în active corporale şi necorporale, with subsequent amendments.

Legea $n r .571 / 2003$ privind Codul fiscal, with subsequent amendments.

Ministerul Finanţelor (1994), Sistemul contabil al agenţilor economici, Editura Economică.

Ministerul Finanţelor (1994), Noile reglementări privind amortizarea capitalului amortizat în active corporale şi necorporale, Editura Economică.

Ordinul MFP nr. 3055/2009 pentru aprobarea Reglementărilor contabile conforme cu directivele europene, with subsequent amendments. 
Ordinul BNR nr. 27/2010 pentru aprobarea Reglementărilor contabile conforme cu Standardele Internaţionale de Raportare Financiară, aplicabile instituţiilor de credit, with subsequent amendments.

Ordinul MFP nr. 1286/2012 pentru aprobarea Reglementărilor contabile conforme cu Standardele Internaţionale de Raportare Financiara, aplicabile societăţilor comerciale ale căror valori mobiliare sunt admise la tranzacţionare pe o piaţă reglementată, with subsequent amendments.

Paraschivescu, M. D., Păvăloaia, W., Radu, F., Fotache G., Patraşcu, L., Bordeianu, G. D., Grosu, O. (2013), Contabilitate: fundamente, aplicaţii, istorie şi personalităţi, Iaşi, Editura Tehnopress.

Pătruț, V., Rotilă, A. (2010), Contabilitate şi diagnostic financiar - fundamente teoretice şi aplicaţii practice, Ediţia a II-a revizuită şi actualizată, Iaşi, Editura Sedcom Libris.

Pântea, I. P., Bodea, Gh. (2008), Contabilitatea financiară românească conformă cu directivele europene, Ediţia a III-a, Deva, Editura Intelcredo.

Ristea, M., Dumitru, C. G. (2012), Libertate şi conformitate în standardele şi reglementările contabile, Bucureşti, Editura CECCAR.

Robu, V., Anghel, I., Şerban E. C. (2014), Analiza economico-financiară a firmei, Bucureşti, Editura Economică.

Toma, M. (2003), Ghid pentru înţelegerea şi aplicarea IAS 16 „Imobilizări corporale”, Bucureşti, Editura CECCAR. 